\title{
52. SUBSIDENCE OF THE KERGUELEN PLATEAU: THE ATLANTIS CONCEPT ${ }^{1}$
}

\author{
Millard F. Coffin ${ }^{2}$
}

\begin{abstract}
Ocean Drilling Program Leg 119 and 120 results from the Southern Kerguelen Plateau provide important constraints on the subsidence history of this large igneous province. Following emplacement of the plateau at $\sim 110$ $\mathrm{Ma}$, sedimentary facies indicate that portions of the feature remained above sea level or in shallow water for up to 40 m.y. I use previously determined age-depth relationships for oceanic lithosphere to determine the level of emplacement for five sites on the Southern Kerguelen Plateau. If thermal subsidence was the dominant tectonic process affecting the Southern Kerguelen Plateau following emplacement, then large portions of the feature were emplaced and began subsiding far above sea level. This resulted in significant erosion and redeposition of volcanic material mixed with biogenic sediment, and a gradual development of facies from terrestrial through terrigenous to shallow water and pelagic. I propose the "Atlantis" concept for this early evolution of the Kerguelen Plateau and of other large igneous provinces that produced a sedimentary record intermediate between continental and oceanic.
\end{abstract}

\section{INTRODUCTION}

The Kerguelen Plateau encompasses an area in excess of one million square kilometers, placing it, with the Ontong Java Plateau in the Pacific Ocean, among the largest expressions of off-axis volcanism yet discovered on the Earth's crust. The bulk of the plateau, together with Broken Ridge, may have been emplaced over a span of only a few million years culminating at $\sim 110 \mathrm{Ma}$ (Whitechurch et al., this volume). Structural interpretations (Houtz et al., 1977; Coffin et al., 1986) divide the Kerguelen Plateau into two distinct sectors, the northern and the southern, with the boundary at $\sim 54^{\circ} \mathrm{S}$ (Fig. 1). The northern sector includes the province's only islands, composed of Eocene and younger volcanic and intrusive rock (Giret and Lameyre, 1983). For the most part, it lies $<1000 \mathrm{~m}$ below sea level, and seismic data reveal the presence of numerous igneous intrusions and/or basement horsts. The southern sector contains no islands, lies between 1000 and $3000 \mathrm{~m}$ depth, and shows no evidence of Eocene and younger volcanism.

The general subsidence history of oceanic plateaus has been the focus of only one study to date (Detrick et al., 1977). A principal conclusion was that subsidence could be attributed to cooling and contraction of the lithospheric plate on which the plateaus were constructed at rates comparable with those of normal oceanic lithosphere, assuming that emplacement occurred close to sea level. Since that study, which did not include analysis of the Kerguelen Plateau, the age-depth relationship of oceanic lithosphere has been documented further and refined (Parsons and Sclater, 1977; Hayes, 1988), and relevant data have been acquired by ocean drilling into the Kerguelen Plateau (Barron, Larsen, et al., 1989; Schlich, Wise, et al., 1989). The presence of Eocene and younger volcanic rocks in the northern sector of the plateau, and the possibility that plateau basement north of the Kerguelen Isles is Eocene and younger (Royer and Sandwell, 1989; Royer and

\footnotetext{
${ }^{1}$ Wise, S. W., Jr., Schlich, R., et al., 1992. Proc. ODP, Sci. Results, 120: College Station, TX (Ocean Drilling Program).

2 Bureau of Mineral Resources, Geology and Geophysics, GPO Box 378, Canberra, ACT 2601, Australia (present address: Institute for Geophysics, The University of Texas at Austin, 8701 Mopac Boulevard, Austin, TX 78759-8345, U.S.A.).
}

Coffin, this volume), strongly suggest that the northern sector has been thermally rejuvenated. Thus, it has been eliminated from consideration. In contrast, the Southern Kerguelen Plateau shows no evidence of Tertiary or Quaternary volcanism. Major normal and possibly transform faults were active in Late Cretaceous time (Coffin et al., 1990), but nothing indicates that the thermal age of the southern sector was reset. In this paper, the age-depth relationships of Ocean Drilling Program (ODP) sites on the Southern Kerguelen Plateau are calculated and tested, and the results discussed.

During Legs 119 and 120 , seven sites were drilled on the southern plateau (Fig. 1). Four of the sites $(738,747,749$, and 750 ) penetrated igneous rock presumed to represent basement of the Kerguelen Plateau. Four of the sites (738, 747, 748, and 750) also recovered Mesozoic sediment documenting the early history of the feature. Two of those sites (748 and 750) recovered volcanic-rich terrestrial sediment from the base of the sedimentary section. Scientists aboard Rig Seismic in 1985 and Marion Dufresne in 1986 (Fig. 1) collected $\sim 5600$ and $\sim 4400 \mathrm{~km}$, respectively, of multichannel seismic (MCS) data, which enabled the drilling results to be extended over broad areas of the Southern Kerguelen Plateau (e.g., Coffin et al., 1990).

Igneous basement at all four sites consists of volcaniclastic rock and altered basalt, with geochemical signatures transitional between mid-ocean ridge basalt (MORB) and oceanicisland basalt (OIB) (Barron, Larsen, et al., 1989; Schlich, Wise, et al., 1989). Basalt flows have a maximum thickness of several meters and show evidence of having been erupted subaerially. Isotopic data at three of the sites $(747,749$, and 750) show no evidence of continental contamination of the basalt (Schlich, Wise, et al., 1989). Lead isotope data, however, from Site 738 indicate some degree of continental contamination (Alibert, 1991). The terrestrial sediment recovered from the Southern Kerguelen Plateau was unexpected; velocity analyses of the MCS site survey data did not reveal a significant velocity inversion that was found to mark the top of the sequence, which consists of silty claystone with coal and other land-derived organic matter (Schlich, Wise, et al., 1989). Mesozoic shallow-water sediment includes algal calciclastic limestone (Site 738; Barron, Larsen, et al., 1989); glauconitic calcarenite (Site 747; Schlich, Wise, et al., 1989); glauconitic sand-, silt-, and claystone, and glauconitic bioclastic grain- 


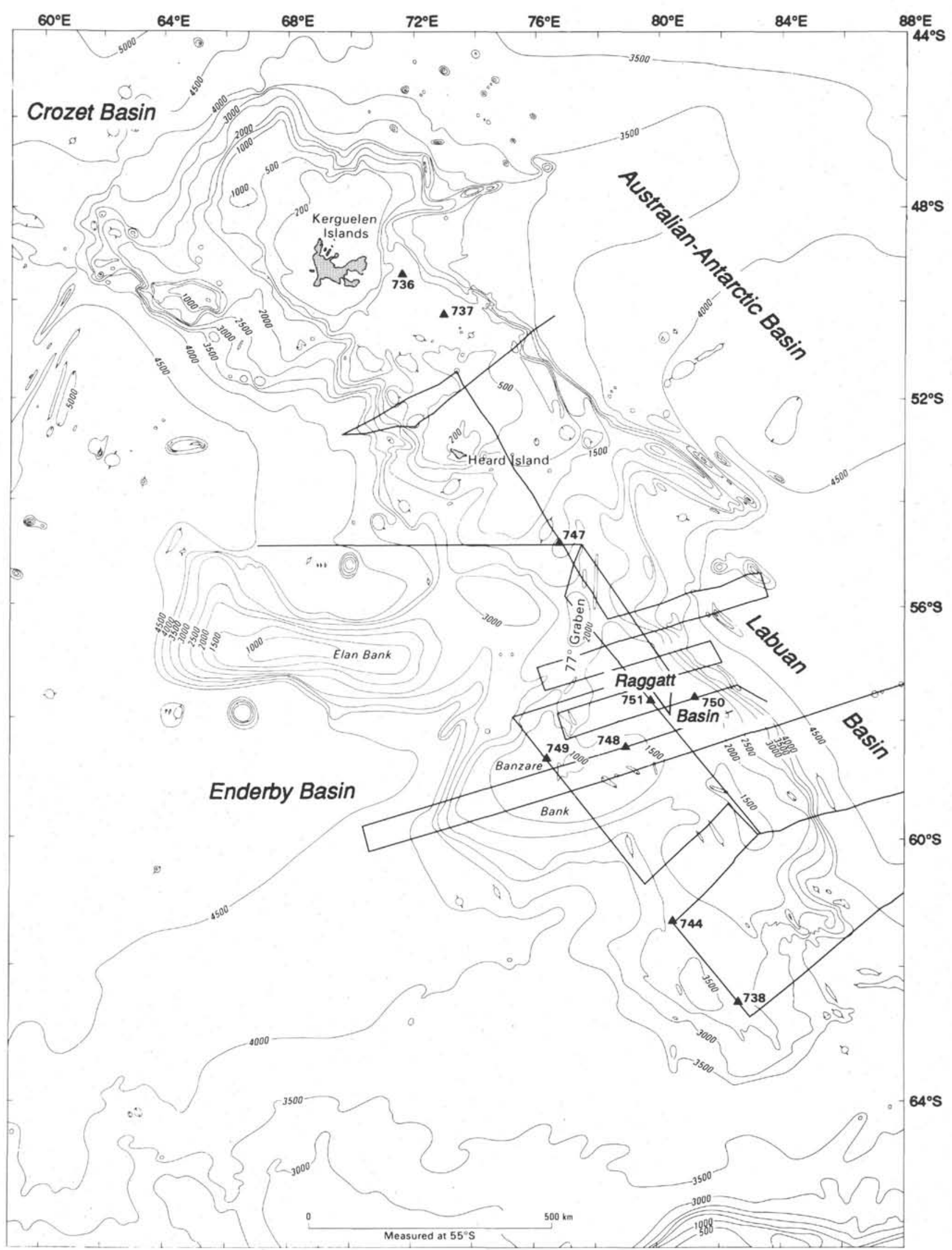

Figure 1. Leg 119 and 120 sites and nonproprietary multichannel seismic (MCS) lines on the Kerguelen Plateau. Bathymetry (in meters) after Schlich et al. (1987). 
stone to wackestone (Site 748; Schlich, Wise, et al., 1989); and calcareous chalk and limestone (Site 750; Schlich, Wise, et al., 1989).

\section{SUBSIDENCE HISTORY}

The procedure for calculating the subsidence history of oceanic lithosphere has been thoroughly documented (e.g., Parsons and Sclater, 1977), and the most relevant study for the Kerguelen Plateau is that of Hayes (1988), who analyzed data from the Southeast Indian Ocean in the rough vicinity of the plateau. The level of emplacement of igneous basement is calculated by the equation,

$$
D_{0}=D_{c}-C \text { age }^{1 / 2},
$$

in which $D_{0}=$ original depth or elevation of emplacement of the crust in meters, $D_{c}=$ present corrected depth of the crust in meters, $C=$ empirical constant in meters, and age is in m.y.

The value of $C$ was determined to be $290 \mathrm{~m}$ for the Southeast Indian Ocean south of the spreading center between $111^{\circ}$ and $119^{\circ} \mathrm{E}$ (Hayes, 1988). This value is close to the global averages of 350 (Parsons and Sclater, 1977) and $300 \mathrm{~m}$ (Hayes, 1988). I note that these averages were determined from Cenozoic age lithosphere; there is no reason to suspect, however, that Mesozoic lithosphere followed different rules of thermal subsidence.

Although Whitechurch et al. (this volume) conclude that formation of the Kerguelen Plateau around Site 749 was complete by $110 \mathrm{Ma}$, this is based on only one sample dated by the ${ }^{40} \mathrm{Ar} /{ }^{39} \mathrm{Ar}$ technique. Five other samples from Sites $747,748,749$, and 750 dated by the same technique yielded dates ranging from 80.3 to $164.4 \mathrm{Ma}$. Seven samples from the four sites dated by the $\mathrm{K}-\mathrm{Ar}$ technique yielded ages from $75.9 \pm 5.9$ to $111.5 \pm 3.2 \mathrm{Ma}$. The only other reported date, $114 \pm 1 \mathrm{Ma}$, was obtained by the $\mathrm{K}-\mathrm{Ar}$ method on a plagioclase from a dredged basalt (Leclaire et al., 1987). No dates have been obtained from Site 738 basalt. More work is clearly needed on dating the cored and dredged basalt, and the $110 \mathrm{Ma}$ date used in the calculations must be regarded only as the best estimate. (1983):

The value of $D_{c}$ was obtained by using Crough's equation

$$
D_{c}=d_{w}+t_{s}\left(\rho_{\mathrm{s}}-\rho_{m} / \rho_{\mathrm{w}}-\rho_{m}\right),
$$

in which $d_{w}=$ water depth in meters, $t_{s}=$ sediment thickness in meters, $\rho_{s}=$ average sediment density in $\mathrm{g} / \mathrm{cm}^{3}(1.90), \rho_{m}=$ upper mantle density in $\mathrm{g} / \mathrm{cm}^{3}(3.22)$, and $\rho_{w}=$ water density in $\mathrm{g} / \mathrm{cm}^{3}(1.03)$.

Detrick et al. (1977) suggested that it is valid to apply age-depth relationships for oceanic lithosphere to oceanic plateaus in the absence of major post-emplacement tectonism that may have resulted in thermal rejuvenation of the lithosphere. As previously noted, some post-emplacement deformation in the form of normal and transform faulting, and sedimentary basin formation occurred on the Southern Kerguelen Plateau (Coffin et al., 1990), but evidence is lacking for thermal rejuvenation manifested as volcanism (Coffin et al., 1986). Some question exists as to the crustal nature of the basalt at Site 738 (Alibert, 1991); studies of continental lithosphere, however, suggest that its subsidence may be dominated by an age-depth relationship similar to that of oceanic lithosphere (Karner et al., 1983). Application of these equations to suitable Southern Kerguelen Plateau ODP sites yield the elevations $\left(D_{0}\right)$ of emplacement shown in Table 1 and depicted in the age-depth curves in Figure 2. Eustatic changes in sea level have not been considered in this analysis. Igneous basement was not penetrated at Site 748 ; Hole $748 \mathrm{C}$ bottomed in sediment beneath a lava flow, and the total sediment thickness was estimated from an interpretation of Rig Seismic MCS data and compressional wave velocities (Schlich, Wise, et al., 1989).

Another approach that could be used to predict emplacement elevations of Southern Kerguelen Plateau sites is the plate model (e.g., Parker and Oldenburg, 1973; Davis and Lister, 1974; Crough, 1975; Parsons and Sclater, 1977). Plate model equations, however, contain one variable, the temperature at the base of the lithosphere, for which little agreement exists, especially in the case of large igneous provinces such as the Kerguelen Plateau (e.g., White and McKenzie, 1989). Calculations of emplacement elevations are sensitive to this, and consideration of a plate model is beyond the scope of this study.

To check emplacement elevations, sediment facies at various sites were examined (Barron, Larsen, et al., 1989; Schlich, Wise, et al., 1989), and it was assumed that the end of shallow-water sedimentation occurred at a depth of $200 \mathrm{~m}$. Assuming a basement age of $\sim 110 \mathrm{Ma}$, depth to igneous basement at the end of shelf deposition may be calculated by the equation:

$$
D_{\text {bes }}=D_{0}+C\left(\text { age }- \text { age }_{e s}\right) 1 / 2,
$$

in which $D_{\text {bes }}=$ depth of igneous basement at the end of shelf deposition in meters, and age $e_{e s}=$ age at the end of shelf deposition in m.y. (using the time scale of Kent and Gradstein, 1985).

Depth to seafloor at the end of subaerial and shallow-water deposition may be predicted by combining the equations of Hayes (1988) and Crough (1983) as follows:

$$
D_{\text {ses }}=D_{0}+C\left(\text { age }-\operatorname{age}_{e s}\right) 1 / 2-t_{e s}\left(\rho_{s}-\rho_{m} / \rho_{w}-\rho_{m}\right),
$$

in which $D_{\text {ses }}=$ depth of seafloor at the end of shelf deposition in meters, and $t_{e s}=$ sediment thickness at the end of shelf deposition in meters.

The various equation parameters, and calculated basement and seafloor depths at the end of shelf deposition are shown in Table 2, and calculated subsidence curves for igneous basement at the various sites are shown in Figure 2.

At Site 738, the age of the youngest shelf facies sediment was inferred to be early Turonian or older (Barron, Larsen, et al., 1989), and the $100 \mathrm{Ma}$ date for the end of shelf deposition is an estimate. The ages for the end of shelf deposition at Sites 748 and 750 are regarded as minimum ages because of poor age control in the terrestrial and terrigenous portions of the sedimentary section. The ages could be in error by up to 10 m.y. Pelagic sediment dated at $\sim 85$ and $\sim 50$ Ma overlies igneous basement at Sites 747 and 749 , respectively; no

Table 1. Equation parameters and elevations of emplacement of Leg 119 and 120 sites.

\begin{tabular}{lcrcr}
\hline Site & \multicolumn{1}{c}{$d_{w}$} & \multicolumn{1}{c}{$t_{s}$} & $D_{c}$ & \multicolumn{1}{c}{$D_{0}$} \\
\hline 738 & 2252.5 & 496 & 2551 & -490 \\
747 & 1695.2 & 297 & 1874 & -1168 \\
748 & 1290.5 & $\mathrm{a}_{1135}$ & 1975 & -1067 \\
749 & 1069.5 & 202 & 1191 & -1850 \\
750 & 2030.5 & 672 & 2435 & -606 \\
\hline
\end{tabular}

Notes: $D_{0}=$ elevations of emplacement. Depths are positive, and elevations are negative.

${ }^{a}$ Estimated. 


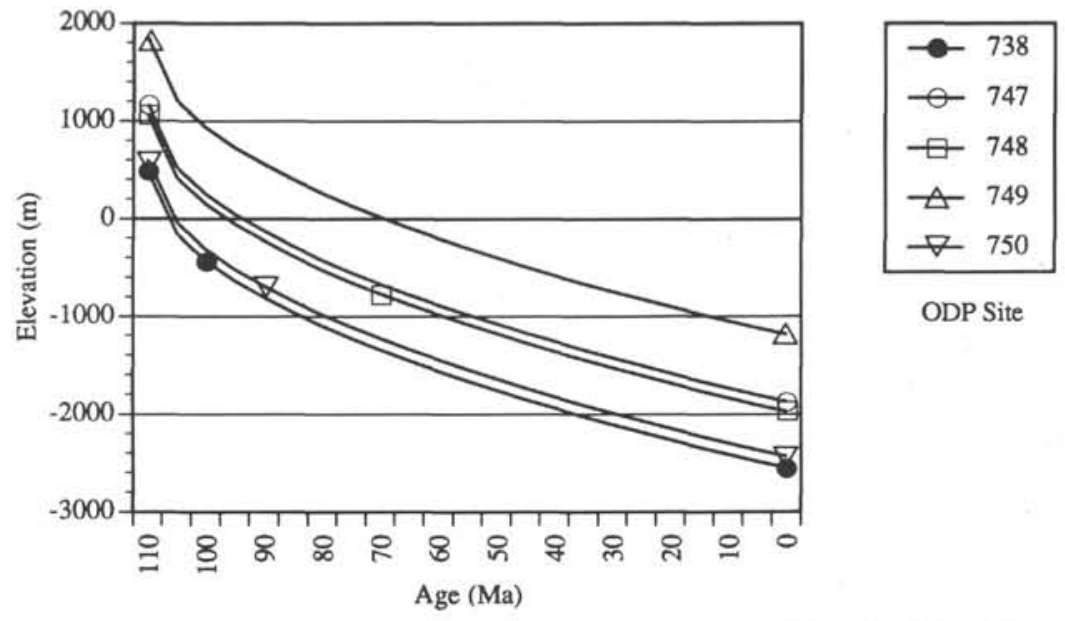

Figure 2. Age-depth curves for igneous basement at Sites 738, 747, 748, 749, and 750. Calculated basement depths for all sites are given for 0 and $110 \mathrm{Ma}$; for Sites 738 , 748 , and 750 calculated basement depths at the end of shelf deposition are indicated. See Table 2 for the corresponding depths to seafloor at the end of shelf deposition.

terrestrial, terrigenous, or shallow-water marine facies sediment was recovered from either site (Schlich, Wise, et al., 1989).

Given potential errors in dates for basement rocks and for the end of shelf deposition, and in the $C$ term of the age-depth equation, the predicted seafloor depths, which lie within a few hundred meters of shelf depths, appear to be reasonable. The age-depth curves for the five sites (Fig. 2) demonstrate that slight dating errors may have a significant influence on basement, and hence seafloor, depths. Interestingly, the oldest pelagic sediment at Sites 747 and 749 corresponds roughly in age to those predicted for basement descending through 200 -m water depth (Fig. 2). The long hiatus at Site 749 may be explained by its remaining above sea level until $\sim 70 \mathrm{Ma}$ or perhaps later. Two other lines of evidence support this by suggesting that significant erosion of basement occurred at the site. One is compressional wave velocities that are higher than those determined from samples from other plateau sites (Schlich, Wise, et al., 1989), suggesting that deeper levels of igneous crust were penetrated. Another is the presence of intermediate zeolite facies (Sevigny et al., this volume), indicating higher temperatures and perhaps deeper levels than the zeolite facies at Sites 747 and 750 . Future subsidence studies should incorporate isostatic corrections for igneous basement removed by erosion.

Table 2. Equation parameters, and calculated basement and predicted seafloor depths of Leg 119 and 120 sites.

\begin{tabular}{clccc}
\hline Site & Age $_{\text {es }}$ & $D_{\text {bes }}$ & $t_{\text {es }}$ & $D_{\text {ses }}$ \\
\hline 738 & $\mathrm{a}_{100}$ & 427 & 16 & 417 \\
747 & $\mathrm{~b}^{2} ?$ & $?$ & $?$ & $?$ \\
748 & $\mathrm{c}_{70}$ & 767 & 410 & 520 \\
749 & $\mathrm{~b}^{2}$ & $?$ & $?$ & $?$ \\
750 & $\mathrm{c}_{90}$ & 691 & 52 & 659 \\
\hline
\end{tabular}

Notes: $D_{\text {bes }}=$ calculated basement and $D_{\text {ses }}=$ pre dicted seafloor depths.

${ }^{\mathrm{a}}$ Estimated.

${ }^{\mathrm{b}}$ Hiatus.

${ }^{c}$ Minimum

\section{CONCLUDING DISCUSSION}

Facies analysis of sediment cored during Legs 119 and 120 indicates that parts of the Southern Kerguelen Plateau remained near sea level for up to $\sim 40 \mathrm{~m}$.y. following emplacement of the feature. Application of empirical agedepth relationships and sediment correction factors to ODP sites on the Southern Kerguelen Plateau complements facies interpretations and suggests that parts of the southern plateau were formed high above sea level. Present-day, but smaller analogs to the Southern Kerguelen Plateau, namely Iceland, Hawaii, and the Northern Kerguelen Plateau (Kerguelen Isles and Heard/McDonald islands), all suggest that subaerial emplacement and early evolution of such large igneous provinces may be the rule rather than the exception. Table 3 summarizes subaerial areas and maximum elevations of these provinces, all of which have been volcanically active in Quaternary time.

It is difficult to ascertain what percentage of the Southern Kerguelen Plateau was above sea level at the end of its constructional phase; the common angular unconformity between basement and overlying sediment, and the widespread distribution of terrestrial/terrigenous seismic facies on the southern plateau (Coffin et al., 1990), however, suggest that much of its $\sim 500,000$ $\mathrm{km}^{2}$ area was at one time above sea level. Samples obtained from the Naturaliste Plateau (Davies, Luyendyk, et al., 1974; Hayes, Frakes, et al., 1975; Coleman et al., 1982), Ninetyeast Ridge (von der Borch, Sclater, et al., 1974; Davies, Luyendyk, et al., 1974; Peirce, Weissel, et al., 1989), Rio Grande Rise (Supko, Perch-Nielsen, et al., 1977), and the Iceland-Faeroe Ridge (Talwani, Udinstev, et al., 1976) also show strong evidence of subaerial basalt extrusion. Furthermore, at least part of the

Table 3. Subaerial areas and maximum elevations of marine large igneous provinces.

\begin{tabular}{lrc}
\hline \multicolumn{1}{c}{ Province } & Subaerial area $\left(\mathrm{km}^{2}\right)$ & Maximum elevation $(\mathrm{m})$ \\
\hline Iceland & 103,820 & 2,119 \\
Hawaii & 10,456 & 4,169 \\
Kerguelen & 7,215 & 1,850 \\
Heard/McDonald & 412 & 2,745 \\
\hline
\end{tabular}


basaltic seaward-dipping reflector sequences drilled on the Vøring Plateau (Talwani, Udinstev, et al., 1976; Eldholm, Thiede, Taylor, et al., 1987, 1989) and Rockall Bank (Roberts, Schnitker, et al., 1984) was erupted and eroded subaerially. Thus, many large igneous provinces appear to have had an early evolution similar to that of the Southern Kerguelen Plateau.

Following the constructional phase of plateau development, erosional processes become the dominant factor in altering plateau morphology if thermal rejuvenation does not keep the feature high-standing. If the plateau is submarine, erosion of basalt and associated extrusive and intrusive rock is negligible. However, if the plateau is subaerial, erosion can be widespread, significantly altering topography of the feature (e.g., Iceland, Hawaii, Kerguelen, and Heard/McDonald). The rate of denudation of any rock is a function of topography and climate. Wood recovered in basal sediment of the Raggatt Basin suggests a temperate climate (Francis and Coffin, this volume), and average denudation rates in temperate climates vary from 10 to $200 \mathrm{~m} / \mathrm{m}$.y., depending on topographic relief (Saunders and Young, 1983). Evidence from drilling on the Southern Kerguelen Plateau suggests that parts of the plateau may have remained subaerial for up to $40 \mathrm{~m}$.y., allowing $400-8000 \mathrm{~m}$ of erosion. Drilling results do not support the latter figure, but several hundred to over a thousand meters of basalt could have been eroded based on compressional wave velocity values (Schlich, Wise, et al., 1989) and zeolite facies (Sevigny et al., this volume). The erosional phase of development was marked by deposition of terrestrial and terrigenous sediment. After the bulk of the plateau subsided below sea level, biogenic shallow-water and pelagic sediment followed.

In conclusion, it appears that many large igneous provinces in the marine realm have experienced a significant portion of their development subaerially and in shallow water. The progressive development of dominantly terrestrial, then terrigenous, and eventually biogenic shallow-water and pelagic facies sediment in response primarily to thermal subsidence is what I coin "Atlantis"'-type evolution.

\section{ACKNOWLEDGMENTS}

I thank the entire complements of Ocean Drilling Program Legs 119 and 120 for obtaining the samples used in this study, and the Bureau of Mineral Resources (Australia) and the Ecole et Observatoire de Physique du Globe-Strasbourg (France) for providing site survey data. A very special thanks to Kerry Kelts for stimulating the ideas presented here, and for providing an idyllic work environment in Kilchberg. I am grateful to John Peirce and John Sclater for critical reviews. Published with the permission of the Director, Bureau of Mineral Resources, Geology and Geophysics, Canberra, Australia. University of Texas Institute for Geophysics Contribution No. 857.

\section{REFERENCES}

Alibert, C., 1991. Mineralogy and geochemistry of a basalt from Site 738: implications for the tectonic history of the southernmost part of the Kerguelen Plateau. In Barron, J., Larsen, B., et al., Proc. ODP, Sci. Results, 119: College Station, TX (Ocean Drilling Program), 293-298.

Barron, J., Larsen, B., et al., 1989. Proc. ODP, Init. Repts., 119: College Station, TX (Ocean Drilling Program).

Coffin, M. F., Davies, H. L., and Haxby, W. F., 1986. Structure of the Kerguelen Plateau province from SEASAT altimetry and seismic reflection data. Nature, 324:134-136.

Coffin, M. F., Munschy, M., Colwell, J. B., Schlich, R., Davies, H. L., and Li, Z. G., 1990. Seismic stratigraphy of the Raggatt Basin, Southern Kerguelen Plateau: tectonic and paleoceanographic implications. Geol. Soc. Am. Bull., 102:563-579.

Coleman, P. J., Michael, P. J., and Mutter, J. C., 1982. The origin of the Naturaliste Plateau, SE Indian Ocean: implications from dredged basalts. J. Geol. Soc. Australia, 29:457-468.
Crough, S. T., 1975. Thermal model of oceanic lithosphere. Nature, 256:388-390.

1983. The correction for sediment loading on the seafloor. J. Geophys. Res., 88:6449-6454.

Davies, T. A., Luyendyk, B. P., et al., 1974. Init. Repts. DSDP, 26: Washington (U.S. Govt. Printing Office).

Davis, E. E., and Lister, C.R.B., 1974. Fundamentals of ridge crest topography. Earth Planet. Sci. Lett., 21:405-413.

Detrick, R. S., Sclater, J. G., and Thiede, J., 1977. The subsidence of aseismic ridges: Earth Planet. Sci. Lett., 34:185-196.

Eldholm, O., Thiede, J., Taylor, E., et al., 1987. Proc. ODP, Init. Repts., 104: College Station, TX (Ocean Drilling Program).

1989. Proc. ODP, Sci. Results, 104: College Station, TX (Ocean Drilling Program).

Giret, A., and Lameyre, J., 1983. A study of Kerguelen plutonism: petrology, geochronology, and geological implications. In Oliver, R. L., James, P. R., and Jago, J. B. (Eds.), Antarctic Earth Science: Canberra (Australian Academy of Science), 646-651.

Hayes, D. E., 1988. Age-depth relationships and depth anomalies in the Southeast Indian Ocean and South Atlantic Ocean. J. Geophys. Res., 93:2937-2954.

Hayes, D. E., Frakes, L. A., et al., 1975. Init. Repts. DSDP, 28: Washington (U.S. Govt. Printing Office).

Houtz, R. E., Hayes, D. E., and Markl, R. G., 1977. Kerguelen Plateau bathymetry, sediment distribution, and crustal structure. Mar. Geol., 25:95-130.

Karner, G. D., Steckler, M. S., and Thorne, J. A., 1983. Long-term thermo-mechanical properties of the continental lithosphere. $\mathrm{Na}$ ture, 304:250-253.

Kent, D. V., and Gradstein, F. M., 1985. A Cretaceous and Jurassic geochronology. Geol. Soc. Am. Bull., 96:1419-1427.

Leclaire, L., Bassias, Y., Denis-Clocchiatti, M., Davies, H., Gautier, I., Gensous, B., Giannesini, P.-J., Patriat, P., Ségoufin, J., Tesson, M., and Wannesson, J., 1987. Lower Cretaceous basalt and sediments from the Kerguelen Plateau. Geo-Mar. Lett., 7:169-176.

Parker, R. L., and Oldenburg, D. W., 1973. Thermal model of ocean ridges. Nature, 242:137-139.

Parsons, B., and Sclater, J. G., 1977. An analysis of the variation of ocean floor bathymetry and heat flow with age. J. Geophys. Res., 82:803-827.

Peirce, J. W., Weissel, J. K., et al., 1989. Proc. ODP, Init. Repts., 121: College Station, TX (Ocean Drilling Program).

Roberts, D. G., Schnitker, D., et al., 1984. Init. Repts. DSDP, 81: Washington (U.S. Govt. Printing Office).

Royer, J.-Y., and Sandwell, D. T., 1989. Evolution of the eastern Indian Ocean since the Late Cretaceous: constraints from GEOSAT altimetry. J. Geophys. Res., 94:13,755-13,782.

Saunders, I., and Young, A., 1983. Rates of surface processes on slopes, slope retreat, and denudation, Earth Surface Processes Landforms, 8:473-501.

Schlanger, S. O., Jackson, E. D., et al., 1976. Init. Repts. DSDP, 33: Washington (U.S. Govt. Printing Office).

Schlich, R., Coffin, M. F., Munschy, M., Stagg, H.M.J., Li, Z. G., and Revill, K., 1987. Bathymetric Chart of the Kerguelen Plateau. Jointly edited by Bureau of Mineral Resources, Geology and Geophysics, Canberra, Australia; Institut de Physique du Globe, Strasbourg, France; and Terres Australes et Antarctiques Françaises, Paris, France.

Schlich, R., Wise, S. W., Jr., et al., 1989. Proc. ODP, Init. Repts., 120: College Station, TX (Ocean Drilling Program).

Supko, P. R., Perch-Nielsen, K., et al., 1977. Init. Repts. DSDP, 39: Washington (U.S. Govt. Printing Office).

Talwani, M., Udinstev, G., et al., 1976. Init. Repts. DSDP, 38: Washington (U.S. Govt. Printing Office).

von der Borch, C., Sclater, J. G., et al., 1974. Init. Repts. DSDP, 22: Washington (U.S. Govt. Printing Office).

White, R., and McKenzie, D., 1989. Magmatism at rift zones: the generation of volcanic continental margins and flood basalts. $J$. Geophys. Res., 94:7685-7729.

Date of initial receipt: 7 September 1990

Date of acceptance: 2 February 1991

Ms 120B-202 